Erkan, G. \& Balbay, S. (2021). How English language instructors coped with the onset of the pandemic and remote language teaching: A case study. Bolu Abant İzzet Baysal Üniversitesi Eğitim Fakültesi Dergisi, 21(4), 1198-1211. https://dx.doi.org/10.17240/aibuefd.2021..-912877

Makalenin Türü / Article Type Geliş Tarihi / Date Received Kabul Tarihi / Date Accepted Yayın Tarihi / Date Published
: Araștırma Makalesi / Research Article

: 10.04.2021

: 06.08.2021

$\cdot 15.12 .2021$

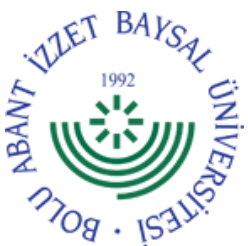

\title{
HOW ENGLISH LANGUAGE INSTRUCTORS COPED WITH THE ONSET OF THE PANDEMIC AND REMOTE LANGUAGE TEACHING: A CASE STUDY
}

\author{
Gökçe ERKAN ${ }^{1}$, Seher BALBAY ${ }^{2}$
}

\begin{abstract}
This paper reports on the emergency remote education period of the instructors at the School of Foreign Languages of a Turkish state university. The university the study was conducted in, along with all other higher education institutions in Turkey, switched to online education with the sudden spread of the COVID 19 pandemic. To evaluate how the instructors dealt with this sudden transition, 110 participants teaching at the School of Foreign Languages completed an online survey at the end of the emergency remote education academic semester. Thereafter 24 of them volunteered to be interviewed about their experiences in more detail. The findings reveal that most instructors had some apprehension and difficulty in making the transition to online teaching, yet still considered themselves competent in dealing with the unexpected and unprepared teaching medium. Many thought the experience had been valuable to their personal development and referred to aspects of online education that will be integral to their professional development. It was observed that the instructors also repeatedly expressed that they perceived the experience as one that interaction among colleagues benefitted them most both in developing their digital skills and in providing them with psychological support.
\end{abstract}

Keywords: Emergency remote teaching, distance education, pandemic period language education, adaptation to educational technology

\section{İNGILIZZCE ÖĞRETIM GÖREVLILERININ PANDEMİ DÖNEMİ UZAKTAN EĞíTIM SÜRECİ: BIIR VAKA ÇALIŞMASI}

\section{öz}

Bu çalışma Mart 2020'de Türkiye'de ilk COVID 19 vakasının görülmesiyle başlayan yeni eğitim şartlarına ODTÜ Yabancı Diller Yüksekokulu öğretim görevlilerinin uyum sürecini incelemek amacıyla yapılmıştır. Bu dönemde Türkiye'de yüksek öğretim kurumlarındaki öğrenciler evlerine gönderilmiş ve hızlı bir şekilde uzaktan eğitime geçilmiştir. Araştırma için veri toplama amaçlı 110 katılımcı uzaktan eğitim süreci hakkında araştırmacıların hazırladıkları çevrim içi bir anket cevaplamış ve gönüllü olan 24 katılımcıyla mülakatlar yapılmıștır. Katılımcıların büyük bir çoğunluğunda sürecin başında zorluk yaşadıkları tecrübesi ortaktır, fakat sürecin zaman içinde katılımcı öğretim görevlilerinde, uzaktan eğitimde gerekli beceriler konusunda yeterlilik hissi yarattığı gözlemlenmiştir. Ayrıca yine katılımcıların çoğu, kişisel gelişimleri açısından, uzaktan eğitim sürecinde kazandıkları beceri ve bakış açılarının, mesleki gelişimlerine katkısının büyük olduğunu iletmiş ve çevrim içi eğitimin ileriki dönemlerde de hayatlarında olacağını belirtmişlerdir. Katılımcı öğretim görevlileri, meslektaş iletişiminden hem dijital becerilerini geliştirme hem de psikolojik destek anlamında çok faydalandıklarını belirtmişlerdir.

Anahtar Kelimeler: Afet durumu eğitimi, uzaktan eğitim, pandemi dönemi dil eğitimi, eğitim teknolojilerine uyum

\footnotetext{
${ }^{1}$ Ortadoğu Teknik Üniversitesi, Modern Diller Bölümü, vgokce@metu.edu.tr, 노ttps://orcid.org/0000-0001-6276-053X

${ }^{2}$ Ortadoğu Teknik Üniversitesi, Modern Diller Bölümü, seherb@metu.edu.tr, 는tps://orcid.org/0000-0003-4248-9257
} 


\section{INTRODUCTION}

Teachers are renowned for their organizational skills and ability to deliver a predetermined curriculum to all comers. As with other professions, their time and methods are planned in detail, and methodologies are prepared along with materials, media, tasks, assignments, and evaluation processes. Yet, any teacher also acknowledges the fact that teaching circumstances do not resemble a laboratory where variables can be limited. Changes in student and teacher motivation, policy and content, and the environment are the "normal" state of any teaching setting any time. The practice of activating learning in others embodies skillsets much prized in a world where flexibility and creative thinking increasingly differentiate our endeavours across all sectors. Skills in teaching are no better illustrated than in times of crisis when natural or man-made disasters can be seen to wreak havoc on whole communities. We witness our educators performing as frontline workers, coping with a novel situation yet remaining effective and delivering accessible education services. The onset of the Coronavirus pandemic is a recent example where institutions across the globe had to shut their doors and turn to emergency remote teaching (ERT). Essentially a moment when a whole new dimension of the challenge was brought to those teaching in communities already suffering a variety of deprivations and imbalances.

As the pandemic took hold, most institutions in Turkey were required to curtail face to face education in compliance with a nationwide effort to limit the spread of the virus. Expectations were that the pandemic would be swiftly brought under control, instructors and students would work from home and continue their classes online. Those attending institutions that were better prepared found they were able to deploy supportive learning practices, networks and technologies that were developed prior to the pandemic with the aim of making learning both more accessible and effective for all concerned. Those less prepared found themselves suddenly bereft of the support they needed from their administrators, trainers, producers of their teaching materials and technical support. Globally, many institutions had neither anticipated, piloted, nor prepared themselves for such an unprecedented eventuality. A lack of contingency that made the sudden and unexpected transition something of a grand experiment (Hodges et al., 2020). Learners and teachers found themselves suddenly and unexpectedly in a situation that cannot be considered in any way as online or distance learning since it was not planned accordingly. A new terminology started to appear in relevant literature because of the major differences between the circumstances that instructors and students had to bear with during the emergent pandemic days and that of distance or online learning that is carefully planned and designed, now referred to as the experience of "emergency remote education".

The 2019-2020 academic year started in September. It was only about a month into the second semester when the COVID-19 pandemic struck. The government announced a lockdown and with the decision of the Council of Higher Education, all teaching in the country switched to the online format. Nobody knew how long the lockdown would last or when face-to-face education could start again. In the first three weeks of the lockdown, the School of Foreign Languages (SFL) continued education using a variety of online platforms. However, it soon became apparent that the lockdown would be prolonged and it was announced by the Council of Higher Education that the entire second term would be undertaken using online education. All instruction, including formative and summative assessment, was to be conducted online. This decision created dissatisfaction and uneasiness among instructors with a lack of knowledge and experience in educational technologies. It cannot be denied that language is best learned in face-to-face environments where there is always enough room for authentic interaction. For this reason, many instructors did not previously feel the need for much technology in their classes. Now faced with delivering online education, they had to learn some new skills while struggling to teach their students in the best way possible. There are around 300 instructors working at the SFL from various backgrounds at different age levels. While it was basically easy for novice teachers to get accustomed to online teaching who are already familiar with the online world in many different forms, the pandemic period turned out to be a chaos for many experienced teachers who are basically digital immigrants trying to sort out how things work in the online world. This new period was not only a time for teaching but also "learning" for them. In the end, the SFL offered their courses in different forms, synchronous/asynchronous, depending on the technical skills of the instructors. Unfortunately, despite the support provided by department administrations, this emergency remote teaching (ERT) period still turned out to be a "burden" for some. The "burden" was rooted mainly in the insecurity the instructors experienced because they had to answer certain questions that they needed to make decisions on. Some of the most common questions raised were about how much of the course content the instructors still were required to cover, whether they could teach the existing content or skills through online education as effectively as face to face education or not, what sort of testing techniques they should be adapting. The instructors also needed to decide on what was worth allocating the synchronous sessions and what could be assigned for students to work on their own (Pu, 2020). Such questions naturally made the instructors' job a daunting task, as Ko and Rossen (2010, p. 12) put it. 


\section{REVIEW OF LITERATURE}

\subsection{ERT and online education}

The brick and mortar schooling system which is infamous for its formalities and fixed structures, and usually not tailor-made for different learning styles, is infact the product of tremendous infrastructure, organization, and economic and human investment. Hence, it is no wonder that online education would require as much preparedness to function efficiently. In "The difference between emergency remote teaching and online learning", it is stated that a typical preparation period for online education lasts "6-9 months before the course is delivered" (Hodges et al., 2020, par. 12). As institutions resort to ERT at very unexpected times, some problems during this process are naturally to be anticipated. ERT is not optional, it is not a choice, but a remedy in undesired and crisis circumstances. In most cases, it has to engage instructors and students in fully remote teaching. Yet, again in most cases, it is perceived to be a supplement for face-to face education during a crisis period, not a permanent curriculum and methodology design. In the same article it is suggested that "the rapid approach necessary for ERT may diminish the quality of the courses delivered" (Hodges et al., 2020). Speed is necessary in an effort to secure the best quality education possible within the circumstances of the situation so that there is not a long interruption on the continuity of education while the brick and mortar schools are closed.

During ERT, instructors are not prepared to continue education through well-prepared and planned tasks, and the students, too, face psychological and technological challenges throughout the process. The instructors too may need support from school administration regarding the educational decisions to be taken but this support may not be at the desired level. For example, synchronous meetings may not be possible depending on the circumstances of the teaching context, and the cause of the ERT (Means et al., 2014).

However, distance education or online learning is quite different and more organized in this sense. First of all, student registration, choice of materials to be used and assessment criteria are all pre-planned. Typically the student-instructor ratio of online courses depends on the design of the course. While rather interactive courses prefer to have fewer number of students per instructor, massive Open Online Courses address larger numbers of students with much less real interaction and communication taking place between the instructor and the student, and the interaction between students with their peers. In blended education, the modality, that is; to what extent the courses will be offered face to face versus the ratio of online education differs according to the design of blended education. While some online courses are self-paced, some are class-paced (Hodges et al., 2020).

Secondly, teacher-preparedness for teaching is quite different in the online context where instructors receive appropriate skills training beforehand. Clearly they need to develop a variety of digital and other skills to be effective online. However, most SFL instructors drafted to deliver ERT may not have such skills and experience even though they have significant teaching experience. Those SFL instructors who previously made minimal use of technology in the classroom may have experienced significant stress during an already stressful period in their lives.

There is not a consensus about the benefit of online education both for teachers and students. In Allen et al.'s (2012) study, the faculty are reported to be usually pessimistic about online education. The researchers reported that almost two thirds of the faculty believe that learning through online courses is inferior to that of face to face classes. Wilkes et al. (2006), also report that the faculty believe that face to face classes promote better learning than online classes. Some instructors appreciate distance education due to its being time and place independent (anywhere-anytime) and enriched content; however, technological flaws, lack of interaction, lack of attendance of learners and its decreasing the importance of the courses, lack of hardware and difficulty of control were also identified as drawbacks of distance education (Barış \& Çankaya, 2016, p. 399).

It is generally accepted that language learning requires interaction; therefore, it is not suitable for distance learning. This assumption was supported by a study conducted by Barış and Çankaya in 2016 to search for the perceptions of the academic staff regarding distance education. The participants generally stated that "theoretical or verbal courses can be given through distance education; however, the courses which require practice and interaction cannot" (Barış \& Çankaya, 2016, p. 399). However, the COVID-19 pandemic period proved to be the opposite by forcing many institutions following a language learning program to go online. Teachers have tried hard to make the impossible possible.

Distance education is not new. It has been applied widely for quite some time all around the world for various purposes. There are pros and cons of online teaching or online learning. It is clearly different from face to face classes. First of all, the roles of teachers and students change considerably. A research study conducted by Community College Research Center (CCRC, 2013) shows that students and teachers have different perceptions regarding their roles in online education. In the study, students reported that instructors should be active in their learning experience. They are the ones responsible to motivate them. 
Students generally perceive online classes as the easy way out. They think it is likely that they can get good grades with less performance. They also think that they can be the passive absorbers of info without much active participation. Research shows that academically stronger students have a tendency towards face to face classes (Driscoll et al., 2012). It was found out that online classes were perceived as easier; therefore, they attracted the weaker students.

Instructors, on the other hand, see their role as more of a facilitator or guide (CCRC, 2013). They feel that students should be independent learners and self-motivated (CCRC, 2013). Though this is the ideal, the reality might be quite different. In Barış and Çankaya's (2016) study, the faculty stated negative views regarding self-autonomy "because of the current student profiles" (p. 400). As instructors are not physically available in classrooms, they expect that students should make the strongest effort in an online class. They should be self-motivated and "operate as self-directed learners" (Nash, 2015, p. 82). Students must take OE seriously and apply themselves accordingly.

The results of the CCRC (2013) study also revealed that students expect instructors to be "on call" all the time including weekends. This result was verified by the study of Mulig and Rhame (2012) as well. Faculty however, does not hold the same view. On the contrary, they believe they should not be on call especially on weekends (CCRC, 2013). However, it is also important to ensure daily communication. Teachers should still continue providing feedback in a reasonably efficient time (Barr \& Miller, 2013) but this time does not need to be extended over the weekends or late at night.

\subsection{COVID-19 and ERT}

The literature on the effects of the COVID-19 pandemic are very recent, yet they do reveal significant findings for the present study. In a broad perspective the literature repeatedly emphasizes the challenges of the dramatic shift from face-to-face traditional education at brick and mortar schools which had not changed its face to a large extent in the last 200 years. The most difficult factor appears to be the fact that neither the instructors nor the students were prepared for the unprecedented circumstances that the pandemic suddenly presented. The adaptation period had to be short for any educational institution. For higher education the mode of instruction in Turkey was online and distant almost without any exceptions. For programs that were not in the medical field the council of higher education urged all universities in Turkey to move to online education which is a situation faced by many universities throughout the world which affected the comfort zone of higher level English language instructors as well (Bond et al., 2004). The instructors in Bond et al.'s study found the methods of making course materials online difficult at first. They also add that the expectations of students had to be ignored while they were not to be totally disregarded, yet, naturally, there was not a preparation period to collect information about student expectations. Wang et al. (2020) emphasize that teachers were deprived of the very essence of their profession, preparedness. Many research focus on the emotion adaptation period of instructors and emphasize that anxiety was a common state which at times led to depressive moods whose effects were observed on the effectiveness of teaching (Baloran, 2020; Bond et al, 2004; Hartshon \& McMurry, 2020; Wang et al, 2020). In addition to the pandemicrelated emotional reactions the language instructors were also worried about the development of some skills, speaking being the most mentioned in the literature (Hartshon \& McMurry, 2020; Wang et al., 2020). Students had very limited opportunities for speaking in the target language, however speaking in the first language was also a requirement for student-student and student-teacher interaction that the face-to-face instruction provided but online instruction lacked (Aksal, 2011). In a research conducted by Hartshon and McMurry (2020) TESOL instructors revealed that they perceived the initial transition as challenging although the process was not perceived to be as challenging later. The uncertainty at the onset of the pandemic led instructors to feel insufficient according to Hartshon and McMurry's (2020) research which traced the transition period and collected data 6 weeks after switching to online education. They also reported that some instructors perceived the online mode of education as a hindrance that actually undermined student language development and created additional stress.

In the light of the literature on emergency remote teaching, the present research aimed to inquire about the sudden transition period to online education from the instructors' perspective. Although teaching requires skills of adaptation to constantly changing teaching circumstances, before the pandemic, the instructors needed to deal with course content or class population related instant decision making skills. However, with emergency remote teaching they had to face and adapt to online teaching when they were not fully prepared for it. They mostly lacked materials shared online, or the knowledge and experience in delivering input via videoconferencing programs or assessing student performance via online assessment tools. Hence the study set out to explore the answers to the following research questions:

1- What are the most common challenges faced by the instructors at the School of Foreign Languages during the emergency remote teaching period?

2- Which digital skills did the instructors already have when they started ERT?

3- Which skills did the instructors develop during ERT?

4- What are the emotional adaptation challenges the instructors had? 
5- How did the instructors deal with the emotional challenges that ERT caused?

\section{METHODOLOGY}

The study was conducted with a mixed-method design in which Creswell's Explanatory Sequential Design was used (Creswell, 2012). As suggested by Creswell, firstly the numerical and short answer data was collected through the self-developed online survey, next this data was analysed to prepare the qualitative data collection tool, the interviews.

The researchers used two main data collection tools, one of which is the self-developed survey exploring the most common challenges and the practices of instructors. The researchers developed the online survey by referring to surveys exploring online education, and also by collecting data on the practices of some instructors in the teaching context of the School of Foreign Languages where the study was conducted. Informal interviews were conducted with ten instructors, so that the researchers could form general ideas about the challenges met by the instructors due to the sudden transition to online teaching before the researchers developed the survey questions. The survey had questions inquiring about the technical challenges the instructors met, the challenges resulting from the digital skills they lacked, the emotional orientations they had to pass through when adapting to the unforeseen new medium of teaching online. The survey was then reviewed by two experts experienced in developing surveys in the field of education. It was piloted by 11 instructors and revised according to the feedback received. The final version was posted online to all SFL instructors. 110 participants responded and 24 of these also volunteered to be interviewed remotely using a variety of communication and video conferencing tools. The answers were transcribed and were analyzed on MAXQDA 2018 software according to a thematic analysis by coding the recurring themes. The thematic coding of sample interviews was also done by an interrater to enable reliability. Thus, some themes were merged.

This study was conducted by instructors at the School of Foreign Languages, at one of the most prominent universities of Turkey. The research setting is an international research university offering English medium instruction to 25,000 students. It has 5 main faculties offering in excess of 40 undergraduate programs and 175 postgraduate ones. The School of Foreign Languages (SFL), provides language education to international standards. The primary goal of the SFL is to enable students to follow their departmental courses, to access and effectively use all kinds of resources related to their academic studies and to use English in their professional lives by communicating in written and oral contexts.

The SFL has two departments, namely, the Department of Basic English (DBE) and the Department of Modern Languages (DML), which work in coordination. The DBE aims to provide the students with English language skills so that they can pursue their undergraduate studies without major language-related difficulty in an Englishmedium instruction university. The DML, on the other hand, builds on this foundation and aims to improve students' language skills and adopt them to follow their classes with a focus on English for Academic Purposes. Students learn about academic ethics and attend a variety of courses that aim to develop their language skills and support their post-graduate endeavors in Turkey and beyond.

\subsection{Ethical approval}

Through out this research the researchers paid utmost attention to abide by the expectations stated in the Higher Educational Institutions Scientific Research and Publication Ethics Regulations. None of the actions stated in the second part of the regulations, under the title "Actions Against Scientific Research and Publications Ethics" were realized.

\section{Ethics Committee Approval Information}

Name of the committee that conducted the ethical evaluation: Middle East Technical University Human Research Ethics Committee

Date of the ethics committee approval: August 4, 2020

Ethics committee approval statement issue number: 28620816/235

\subsection{Participants}

110 School of Foreign Languages instructors participated in the study by taking the online self-developed survey exploring their transition period from face to face teaching to online teaching in the spring semester of the 20192020 academic year. About half of the participants (42.4\%) were between the ages 36-45, and 33 percent of the participants were between the ages 46-55.

A very small percentage of the participants were experienced in teaching for less than 6 years. One in five had 1216 years of experience and one in four had 2-6 years of experience. Similarly, most participants have been teaching 
at the same institution the research was conducted for more than seven years. The pie chart below represents the participants' teaching experience at this university. There was a roughly diverse population of experienced and novice teachers teaching students with different levels of proficiency in English.

While $62 \%$ of the participants teach at the Department of Basic English, 37.3 of the participants are instructors of the Modern Languages Department whose largest percentile is composed of instructors teaching the integrated skills course which focused mostly on reading and writing skills, ENG102, which makes of 58.55 of the participants from MLD.

\section{RESULTS}

The questionnaire analyzed the instructors' familiarization with the internet tools they used before the emergency remote teaching period. As ODTUClass, the Learning Management System of the university, was a platform used in the university for sharing course content, reaching out to students in many forms, and used for giving feedback and uploading grades, it was by far the most widely used tool among the instructors. It was followed by another tool developed for educational purposes, Blackboard, with almost a similar percentage (43.6). However, it is interesting to note that even before the emergency teaching period, many instructors were familiar with online meeting tools, such as Zoom (20.9\%) when there was as then no need for meetings in the virtual environment. The interviews revealed that a number of instructors were confident users of other tools such as Google Meet, Microsoft Teams, Webex and so on.

All participants had an internet connection prior to the emergency remote teaching period and access to a computer. A great percentage of instructors also owned the necessary equipment such as headphones (85.5\%), microphone $(69.1 \%)$ or video camera $(68.2 \%)$ together with their computers. In the interviews, it was found that instructors who had not previously integrated technology into their classes, did so during the ERT. Some of the participants even reported that their attitude toward technology integration changed after they tried out certain programs especially because it increased student autonomy.

The next question in the survey, item 9 , asked for the technical equipment used by instructors during the emergency remote teaching period and the responses yielded similar results and percentages with the previous item in the survey, computer $(98.2 \%)$, internet $(96.4 \%)$, headphones/earphones $(75.5 \%)$, microphone $(68.2 \%)$ and video camera $(63.6 \%)$ as being the most widely used equipment respectively.

As for the teaching aids used in classes, a great number of instructors mentioned having used online assignments (95.5\%). A common tool for delivering content, PowerPoint slides, were commonly preferred by instructors (63.6\%). Generally used for assessment purposes, online quizzes and exams $(60 \%)$ have also become an integral part of instruction during the period of ERT. In addition, half of the instructors chose to supplement their course materials with videos available online while a third also chose to use videos they had made themselves.

A large percentage of instructors stated that they had experienced a state of panic at the beginning of ERT. In the interviews too, instructors repeatedly expressed having experienced panic and frustration especially at the beginning of the confinement period.

A significant majority of the participants believe that ERT requires teacher-expertise in technology. One of the interesting comments during the interviews was about ERT turning teachers into students since they had to update their knowledge of interfaces to reach students, Web 2.0 tools, educational technology in general. Being an instructor during ERT was in fact at the same time being a student of technology who had to be autonomous and motivated enough to continue learning no matter what.

The recurring key word that summarises the emotional reaction of the instructors was "panic". While a majority of the instructors said they had experienced a smooth transition to ERT, almost a third of the participants experienced some difficulties. In the interviews, participants typically lamented not being able to plan ahead as they were used to. One reason they mention was the uncertainty surrounding the period that ERT would need to be the modus of instruction and the time available for preparation. The government had initially announced that universities would be closed for 3 weeks to enable preparations for ERT delivery. However this period was subsequently reduced to 1 week. Clearly most instructors were not in favour of this approach and resented the change, some even stating that at the time they were convinced by the narrative that face-to face instruction would resume within a few weeks of the start of the semester.

The results show that most MLD instructors perceived the pandemic confinement period as an opportunity to develop new skills or especially adapting to new teaching styles, and that they could adapt and use some programs, apps or tasks designed for the ERT period during face-to-face teaching. However, some instructors, mostly from the DBE, were less optimistic about the transferability of the skills they had developed during the confinement. One such transferrable change to face-to-face education is the change in the approach to assessment. Apparently, the synchronous paper and pen assessment types of traditional teaching do not work as efficiently as they do in 
class. Especially MLD instructors reported that they took up take-home assignments which led to an inflation in grades, yet this did not cause a major problem since it was not an indication for learning not taking place.

Our survey found that almost $40 \%$ of instructors were initially unfamiliar with online teaching tools and a third of all instructors had experienced frustration due to technical problems while teaching online. That being said about $40 \%$ of participants said they had no such negative experiences. One of the participants reported that even though she herself was familiar with online teaching tools, her students either did not have the necessary means or for other reasons preferred to keep their videos off during synchronous classes and this made it difficult for her to feel the presence of the students when teaching during ERT. She stated that motivation was one of the major factors that hindered student participation during synchronous ERT sessions online.

Only a quarter of instructors stated that the institution provided them with the technical equipment they required when they needed it. Most were ambivalent about this and only one in ten instructors felt that the department had not provided for their technical needs. The difference may be attributed to the degree of support expected from the department administrations. For many familiar with using digital technology, the support they needed included some decisions to be taken regarding the form of teaching sessions, synchronous vs asynchronous, or the forms of assessment. Being clear and standard regarding these issues were enough for such instructors. However, for some others, support about how to use digital platforms or how to adjust computer hardware was a basic necessity. The department administrations may not have prepared themselves sufficiently in this regard. Support was ultimately mostly derived from peers who shared their knowledge and helped their colleagues with their expertise. Such a cooperative environment; however, strengthened the unseen bonds between the members of the institution.

Most of the instructors reported that student attendance was low during ERT. In the interviews, the participants repeatedly mentioned a stark difference in student circumstances they noticed during their Zoom or Webex sessions during synchronous meetings. While some students seemed to be enjoying the comfort of their family homes with unlimited wifi, some were having to cope with difficult study environments. This deprived group was in either student housing or dormitory rooms shared with other students. They were typically harder to engage and were less likely to communicate. Other students were simultaneously caring for older or younger family members as schools were closed and some parents still worked even during the confinement days.

Instructors' opinions on how well their students adapted to online teaching were diverse. While a majority agreed with the statement: "My students adapted to online learning easily." a quarter of them were noncommittal. In the interviews the assets of ERT for students came up recurrently. ERT had its advantages as well, for example, the recorded sessions benefitted the students since they had the chance to watch them as many times as they needed at their own convenience.

The vast majority of participants do not think that ERT was motivating for students. Similarly, most of the instructors did not believe that ERT was an effective medium for learning. In fact, $40 \%$ of the instructors were undecided about whether it was effective or not, yet $25 \%$ disagreed with the statement that ERT is an effective medium for learning. However, in the interviews, the participants also stated that ERT provides alternative methods for teaching. While it was the only alternative during the pandemic period, the participants did not think that it was more advantageous than face-to-face teaching. In this sense, the participants' perception of online education is basically a kind of additional supplement to a course that may be used to support course objectives when necessary.

The results we obtained illustrate the difficulty instructors experienced in having to adapt to sudden and unexpected changes in the medium of instruction within the particular context of the onset of the pandemic. One reason for this was the difficulty of keeping a work-life balance. The majority of instructors indicated that "ERT created an extra workload on top of my daily chores". Another commonly-mentioned reason was the lack of digital skills. A recurring theme mentioned by most instructors was the different computer literacy levels of students from diverse backgrounds. Some students were perceived to be confident and computer literate, motivated to seek technologyrelated problems, while others were demotivated by their lack of computer literacy and perceived themselves to be excluded. Indeed we heard from instructors who said that they felt responsible for compensating for students' lack of technological equipment, skill or interest.

A very high percentage of instructors did not perceive emergency remote teaching as a replacement for face-toface teaching (32.7\%). 22.7\% of the instructors were neutral about the statement: "Emergency remote teaching is an efficient replacement for face-to-face teaching". There were some instructors who believed that online education can only supplement face-to face education and online education should not be relied on to replace faceto-face language education because they found interaction via videoconferencing tools was not genuine in its nature. Likewise, most of the instructors did not think that ERT enhanced the quality of instruction $(26.6 \%$ neutral and 35.8\% disagreed with the statement "Emergency remote teaching enhances the quality of education". Most participants stated that language cannot be taught online. 30\% disagreed with the statement that "Language cannot 
be taught online". And 14\% disagreed with the statement. Hence, the instructors' leniency was towards believing that languages can be taught online.

Instructors were divided as to whether "Emergency remote teaching is more time-saving than face-to-face teaching". In the interviews, some instructors reported that ERT saved time because they did not need to commute to campus and also because they omitted materials and exercises that they would normally use and delivered only the gist of the content during their correspondence with the students. Yet, on the other hand, there were participants who stated that they spent even more time than usual to adapt their course materials to online education. Participants also reported a change in their choice of question types. Some instructors stated that they used more open-ended questions in face-to-face classes. As it is common for both students and instructors to have a quota for using the internet, instructors also used more short answer questions such as True/False questions or multiple choice questions. One instructor stated that she intended to train herself to be more patient when it comes to wait time. About time allocated to giving input, she decided to lessen it since it is more challenging to keep students engaged.

When it comes to how practical ERT was found by the participants, 26.4 percent were neutral about the statement "ERT is more practical than face-to-face teaching". Yet, 30\% of the participants disagreed with its being more practical. Similarly, a majority thought that ERT did not enhance the quality of education.

One of the main aims of language teaching is to make language learners autonomous. Many instructors stated that they found ERT to be more in line with this aim as students adopted a more active role in their learning process. The instructors were there to guide learners in this path. However, in the interviews, the instructors also mentioned that in addition to the traditional teacher roles of instructors as facilitators of learning, the instructors assumed the role of being a facilitator of the medium for instruction as well during ERT, when they had to arrange video conferencing meetings for synchronous classes or when they delivered the input through videos, slides or handouts or when they referred students to resources and course materials.

A very significant outcome of the study is that almost all the participants stated that they felt more comfortable with online teaching at the end of the semester compared to when they first had to implement it. While a number of instructors used the words "panicked" and "terrified" to describe the first days of the ERT period, they usually preferred to use "more comfortable" or "being in control of things" for the last days of the semester. This is an indicator of the change the instructors went through during the process.

Most instructors stated the reason for disliking ERT at first as being unprepared, not knowing what to expect, being inexperienced about using the online teaching tools, especially the synchronous videoconferencing tools, such as WebEx or Zoom. Some instructors expressed that the ERT made them feel as if they were inexperienced in teaching, some stated that they felt just like novice teachers do when they first start teaching, which affected their motivation the most. One specific new concept was having to get used to the screen occasionally not being able to see a single student with their camera turned on. Maintaining eye contact is a humanizing act, especially when the process of teaching and learning is concerned. For many instructors, not being able to have genuine face-to-face interaction was frustrating.

Interestingly, while the instructors complained about the obligation of learning new educational technology and methodology at the beginning of the lockdown, when the interviews were conducted at the end of the ERT semester, they reported their experience as positive, rather than negative owing to the learning experience they had gone through. A positive feature that stands out when ERT is considered is that it enhances teacher and student autonomy. On the part of the students, the fact that they had to take full responsibility for their own learning process was a recurring comment in the interviews conducted. This was also a comment shared by almost all instructors as the ultimate aim in any kind of teaching environment is to make learners autonomous.

When asked what they would have done differently if they were to teach online again using the experience they have gained during ERT, many instructors said that they would do more synchronous teaching. Moreover, more exercises, more practice material and practice quizzes for student engagement especially assigned right after the input sessions. One instructor mentioned the need to improve the programs used for synchronous teaching to be able to share materials when at the same time still teaching. Most reported that the university provided technical support both in terms of access to educational online tools and in terms of guidance in using them. During the interviews the instructors emphasised that there should be more active student participation during online teaching and attendance should be expected rather than voluntary. According to the interviews, among the suggestions for future online teaching periods are interactive exercises and e-books, compulsory attendance.

The instructors believe that an open minded attitude is required to be able to cope with ERT. 


\section{DISCUSSION AND CONCLUSION}

The results of this study highlight some important points to consider for any institution which is planning to go online or implement blended classes. For distance education, it is strongly suggested that necessary preparations should be made and some precautions should be taken in order to increase the readiness level of learners and instructors. Institutions must have a clear teaching plan and a reliable technical delivery system to prevent possible technical problems before applying distance education. As this study showed, teachers complain a lot when they suffer from technical inadequacies. Technical problems not only affect teachers but also students. Khanlarian and Singh (2014) found that students are frustrated when there are IT issues. Student frustration is important as it is correlated to student's success. In an institution pursuing online education, there should be a centralized technical support team or system that both students and instructors may rely on. Prior to online classes, instructors should receive professional training about the technology used for the courses and technical assistance should be available to the instructors when needed.

The same technical help should also be provided to students for them to make the best use of online classes and to ensure that they will be successful in online courses. Providing academic staff with in-service training, getting feedback during distance education and making necessary changes will improve the quality of education offered.

It should not be forgotten that being overambitious in online classes may pose a serious threat both for teachers and students. Therefore, it is better to keep the standards at a minimum and opt for simplicity in materials development, design and delivery. Teachers' instructions should be very specific with the use of rubrics given in advance, preferably in the course guide (Thiede, 2012). The students should have a clear idea of what is expected of them or what the instructor is looking for when grading an assignment. The assignments should also cause students to engage in research, discuss the course material with others and force them to take an analytical approach (Thiede, 2012).

Different from ERT, the successful delivery of online education requires that necessary actions are taken prior to launch. These include supplying the technical equipment needed by instructors, improving the technical infrastructure to make sure that things run smoothly, training instructors for online education (both in terms of computer literacy and educational pedagogy) and informing learners about the goals, rules, and regulations of online education.

In this study, it has been found out that teachers have been more engaged in a tailor-made mode of instruction. They cared more for their students' individual needs. This sometimes involved concerns regarding financial/technical equity issues among students.

Yet there remain "technophobic" teachers even in the 21st century. As a participant in the interviews said, "The pandemic has made my approach to the internet and technology less frightening because I had to overcome all my doubts to be able to teach". A similar attitude was common among the instructors interviewed. One can infer that in fact, from a positive point of view, this pandemic period was "a blessing in disguise" for many. It turned out to be a learning opportunity; however, this did not mean starting everything from scratch. The fundamentals in education remained constant only the mode of instruction changed.

From March to June of 2020 in Turkey, teachers teaching any course or at any level, and at both private and state educational institutions somehow had to adapt to a new mode of teaching. Actually, this was not a new skill for teachers to develop as they are quite adaptive to different contexts, students or materials. The crisis accelerated the adaptation period to existing trends. The COVID-19 pandemic proved to be no different in this sense. The fundamentals about education still persisted but teachers became more open to new trends especially in educational technology. This was not a time of revolution but transition. Instructors started bringing up a change in the direction of learning. As quite a number of participants in the interviews mentioned, teachers were in a state of constant integration of tools to switch to a more student-centered methodology to make learning more effective. Teachers shifted from their basic role of information-providers or deliverers of content more to nurturers or facilitators of learning. They started teaching input or content material less and using fewer materials as the online world provides a fruitful platform for such purposes. The students also had to accept self-study is a must, which led to increased learner independence.

During the COVID-19 pandemic, there was an increase at the level of teachers' anxiety as they found themselves in the midst of demanding new teaching methods and unfamiliar media. As stated in some earlier studies, teachers are most of the time not trained in the necessary technical and pedagogical skills to integrate digital technology into their instruction (Schleicher, 2020). However, the pandemic made teachers real learners once again. Especially in these times of unexpected hardship, it is important that teachers be guided through immediate training sessions on online education to be able to gain the required skills and develop their self-confidence in distance education (Şevik \& Yücedağ, 2021). The participants in the study of Aky1ldı (2020) also highlighted the importance of teachers' being trained on distance education and technology use and added that teachers need to be introduced to 
some EFL teaching methods including an adaptation of communicative approach and interaction to distance education.

This study concluded that for most of the participants, the ERT period was a time for self-investment. With the help of the technical knowledge they gained, teachers had a new repertoire of skills at their disposal. They used their creativity more, became more flexible and turned out to be risk-takers. They found innovative ways to better manage their time both in and outside class. This was not an individual fight against technology as in their opinion a sense of collective hardship emerged that in turn served to strengthen bonds between colleagues, ultimately leading to a greater sense of community and collaboration as mentioned by the participants of the study.

There were obstacles for some teachers as well. Though some instructors embraced the flexibility online teaching provided, some others dreaded the idea as it upset their work and private life balance. Boundaries between work and home life have merged. The need to be available during the day more was a kind of limitation. Some instructors stated that they had difficulty organizing their daily household chores together with working from home. This result was in line with some similar studies conducted in the COVID-19 pandemic era. MacIntyre et al.'s (2020) study also revealed that teachers found balancing personal and professional roles challenging. They stated that "online delivery of courses with work-at-home protocols and ubiquitous online work-related activity creates a lack of physical, temporal and/or psychological boundaries between school and home".

Teachers enjoy their role and facing their students. The study concluded that instructors perceived the computer screen as a barrier in this sense. Not being able to see their students in person was demotivating. It was hard to "connect" when learners were invisible especially in a language classroom where interaction is an indispensable element.

In this time of hardships, educators have proven that they can still rise to the challenges and not be defeated by inadequacies. Thanks to modern technology, education is still possible and a vital activity for communities everywhere. However, it should be noted that the COVID-19 pandemic has changed people's perception of teaching and learning. There have been changes in many instructors' values and beliefs regarding the use of materials, in addition to their roles as teachers and assessors. These newly-gained skills will pave the way for teachers in the future towards a more hybrid form of teaching.

The Edtech industry has been available since the 1990s and improving together with technological advancements; however, it used to be avoided by many instructors in the past. The current pandemic created an experimental opportunity for the edtech industry to demonstrate its benefits. As instructors got to learn and experience the positive aspects of this new world, they realized that edtech is not only to be used in a case of crisis or emergency but in the delivery of normal modes of education as well. It can be said that online tools will definitely be an integral part of instruction for many instructors in the future. Clearly ERT requires best fit with available technology as seen in some Afganistan examples when it was provided via radio programs (UNESCO, 2011).

The study also bears importance for teacher education programs. Being a teacher is stressful at the best of times due to heavy workloads and time constraints, and most of all due to the constantly changing factors affecting the instant decision making mechanisms of teachers. However, a teacher is expected to develop strategies to deal with stress, which is "an invaluable skill that all pre-service and in-service teacher education programs should be integrating as a fundamental professional competence" (MacIntyre et al., 2020). In addition, it can also be concluded that to be able to teach 21 st century students, teachers are to be equipped with the digital skills to be able to teach their way. If the aim of any teaching program is to engage students, integrating educational technologies into instruction will prove to be effective even when it is not an emergency teaching period. Therefore, it is important that prospective language teachers familiarize themselves with these educational tools during their pre-service programs. Şevik and Yücedağ (2021) in their study concluded that none of the participant teachers in their study received training on distance education during their undergraduate studies and proposed to integrate distance education courses for pre-service teacher training programs at universities.

It should be noted that effective teaching pedagogy remains the same regardless of the context. Teachers should always keep their students' needs and weaknesses at the forefront. There will still be instructors who are hesitant about using technology in their classes. However, change will definitely come but not in the form of a revolution and it will inevitably be accepted as witnessed during the first wave of the COVID-19 pandemic. 


\section{REFERENCES}

Aksal, F. A. (2011). Action plan on communication practices: Roles of tutors at EMU Distance Education Institute to overcome social barriers in constructing knowledge. The Turkish Online Journal of Educational Technology, 8(2), 33-47.

Akyıldız, S. T. (2020). Pandemi döneminde yapılan uzaktan eğitim çalışmalarıyla ilgili İngilizce öğretmenlerinin görüşleri (bir odak grup tartışması). Rumelide Dil ve Edebiyat Araştırmaları Dergisi, 21, 679-696. https://doi.org/10.29000/rumelide.835811

Allen, E., Seaman, J., Lederman, D., \& Jaschik, S. (2012). Conflicted: Faculty and online education, 2012. The Sloan Consortium. http://www.insidehighered.com/sites/default/server_files/survey/conflicted.html

Barış, M. F. \& Çankaya, P. (2016). Akademik personelin uzaktan eğitim hakkindaki görüşleri. International Journal of Human Sciences, 13(1), 399-413. https://doi.org/10.14687/ijhs.v13i1.3378

Barr, B. A., \& Miller, S. F. (2013). Higher education: The online teaching and learning experience. Online Teaching and Learning. http://files.eric.ed.gov/Fulltext/ED543912.pdf

Baloran, E. T. (2020). Knowledge, attitudes, anxiety, and coping strategies of students during covid-19 pandemic. Journal of Loss and Trauma, 25(8), 635-642. https://doi.org/10.1080/15325024.2020.1769300

Bond, C. S., Fevyer, D., \& Pitt, C. (2004). Student reactions to online tools for learning to use the internet as a study tool: Outside the comfort zone? In R. Atkinson, C. McBeath, D. Jonas-Dwyer \& R. Phillips (Eds), Beyond the comfort zone: Proceedings of the 21st ASCILITE Conference. Perth.

Community College Research Center. (2013). Creating an effective online environment. Teachers College, Columbia University. http://ccrc.tc.columbiaEdu/media/k2/attachments/creating-effective-onlineenvironment.pdf

Creswell, J. W. (2012). Educational research. Pearson.

Driscoll, A., Jicha, K. A., Hunt, N. A., Tichavsky, L., \& Thomson, G. (2010). Can online courses deliver in-class results? A comparison of student performance and satisfaction in an online versus a face-to-face introductory sociology course. Teaching Sociology, 40(4), 312-33. https://doi.org/10.1177/0092055X12446624

Hartshorn, K. J., \& McMurry, B. L. (2020). The effects of the Covid-19 pandemic on ESL learners and TESOL practitioners in the United States. International Journal of TESOL Studies, 2(2), 140-156. https://doi.org/10.46451/ijts.2020.09.11

Hodges, C. B., Moore, S., Lockee, B. B., Trust, T., \& Bond, M. A. (2020, March 27). The difference between emergency remote teaching and online learning. https://er.educause.edu/articles/2020/3/the-differencebetween-emergency-remote-teaching-and-online-learning

Khanlarian, C., \& Singh, R. (2013). An exploratory study of the online learning environment. Issues in Accounting Education. 29(1), 117-147. https://doi.org/10.2308/iace-50614

Ko, S., \& Rossen, S. (2010). Teaching online: A practical guide (3rd ed.). Routledge.

MacIntyre, P. D., Gregersen, T., \& Mercer, S. (2020). Language teachers' coping strategies during the Covid-19 conversion to online teaching: Correlations with stress, wellbeing and negative emotions. System, 94, 102352. https://doi.org/10.1016/j.system.2020.102352

Means, B., Bakia, M., \& Murphy, R. (2014). Learning online what research tells us about whether, when and how. Routledge Taylor \& Francis Group.

Mulig, L., \& Rhame, S. (2012). Time requirements in an online teaching environment: How to be more effective and efficient in teaching online. Journal of Accounting and Finance, 12(4), 101-109.

Nash, J. A. (2015). Future of online education in crisis: A call to action. The Turkish Online Journal of Educational Technology, 14(2), 80-88.

$\mathrm{Pu}$, H. (2020). Implementing online ELT in the time of crisis: Ordeal or opportunity? ELT Journal, 1(4), 345-348.

Schleicher, A. (2020). Education disrupted — education built. Spotlight: Quality education for all during Covid-19 crisis. OECD/Hundred Research \# $\quad$ Report $\quad$ https://hundredcdn.s3.amazonaws.com/uploads/report/file/15/hundred_spotlight_covid-19_digital.pdf

Şevik, M., \& Yücedağ, Z. (2021). An evaluation of distance education during the Coronavirus-19 pandemic: The views of Turkish EFL teachers. Ĕ̈itim Bilimleri Enstitüsü Dergisi, 9(11), 171-190.

Thiede, R. (2012). Best practices with online courses. US-China Education Review, A2, 135-141. https://eric.ed.gov/?id=ED532176

Wang, C., Pan, R., Wan, X., Tan, Y., Xu, L., Ho, C. S., \& Ho, R. C. (2020). Immediate psychological responses and associated factors during the initial stage of the 2019 coronavirus disease (COVID-19) epidemic among the general population in China. International Journal of Environmental Research and Public Health, 17(5), 17-29.

Wilkes, R. B., Simon, J. C., \& Brooks, L. D. (2006). A comparison of faculty and undergraduate, student perceptions of online courses and degree programs. Journal of Information Systems Education, 17(2), $131-140$. 
UNESCO (2011). Understanding education's role in fragility: Synthesis of four situational analyses of education and fragility: Afghanistan, Bosnia and Herzegovina, Cambodia, Liberia. https://unesdoc.unesco.org/ark:/48223/pf0000191504 


\section{GENIŞ ÖZET}

\section{Gİiș}

Bu çalışma Mart 2020'de Türkiye'de ilk COVID 19 vakasının görülmesiyle başlayan yeni eğitim şartlarına ODTÜ Yabancı Diller Yüksekokulu öğretim görevlilerinin uyum sürecini incelemek amacıyla yapılmıştır. Bu dönemde Türkiye'de yüksek öğretim kurumlarındaki öğrenciler evlerine gönderilmiş ve hızlı bir şekilde uzaktan eğitime geçilmiştir. Olağan süreçlerde oldukça planlı çalışan öğretmenler için büyük ve ani bir değişim gerektiren pandemi şartlarında eğitim araştırmanın katılımcıları olan Yabancı Diller Yüksek Okulu öğretim görevlileri için de bir uyum çabası gerektirmiştir. Eğitimin okul binalarının dışına çevrimiçi ortamlara birden taşınması ihtiyacı uzaktan öğretimi zorunlu kılmıştır. Bu dönemde yeterli çevrim içi kaynak bulunmaması ve çevrim içi eğitim platformlarına aşina olmamak okutmanlar için bir zorluk yaratmıştır. Literatürde çevrim içi eğitimin yüz yüze eğitime iyi bir alternatif oluşturduğu ve daha çok öğrenciye, öğrencinin kendi öğrenme biçimi ve hızında, kendine uygun zamanda ulaştığı belirtilmektedir Bunun yanında önceki araştırmalara göre öğretmenler için hazırbulunuşluk durumları eğitimin sürdürülebilir olması açısından önem arz etmektedir. Ayrıca daha önce yürütülmüş araştırmalar gösteriyor ki öğrenci beklentileri öğretmenlerin acil durum uzaktan eğitim sürecini yönetmelerinde belirleyici rol oynamaktadır. Bir başka veri ise acil durum uzaktan eğitim süreçlerinde özellikle konuşma becerisi geri plana atılan ve yeterince geliştirilemeyen bir beceri olarak öne çıkmaktadır. Literatürde, başta yaşanan zorluklar adaptasyon süreci özellikle mesleki ve duygusal paylaşım ve yardımlaşma ile aşıldığında uzaktan eğitimin daha baş edilebilir olduğu rapor edilmiştir. Literatürde afet durumu veya acil durum uzaktan eğitim süreçlerini konu alan çalışmalar olsa da COVID 19 pandemi süreci kendine özgü özellikler taşımakta ve bu sürede öğretim görevlilerinin adaptasyon süreci belli stratejilerin belirlenmesi açısından önemli ve aydınlatıcıdır. Bu nedenle bu çalışma bir devlet üniversitesinde çalışan Yabancı Diller Yüksek Okulu okutmanlarının acil uzaktan eğitime geçiş süreçlerini konu almıştır. Okutmanların en çok zorlandığı konular, bilgisayar ve interneti çevrim içi eğitim amaçlı kullanım becerileri, bu süreçte geliştirmek durumunda kaldıkları beceriler, duygusal adaptasyon süreçleri ve karşılaştıkları zorluklarla baş etme stratejileri çalışmadaki araştırma sorularıdır.

\section{METOD}

Araştırma için veri toplama amacıyla 110 katılımcı uzaktan eğitim süreci hakkında araştırmacıların hazırladıkları çevrim içi bir anket cevaplamış ve gönüllü olan 24 katılımcıyla mülakatlar yapılmıştır. Katılımcıların \% 42.4'ü 36-45 yaş aralığındadır, \%33’ü ise 46-55 yas aralığındadır. Katılımcıların çoğu 12-16 yıl öğretmenlik tecrübesine sahiptir ve araştırmanın yürütüldüğü eğitim kurumunda 7 yıldan fazla çalışmışlardır. Katılımcılar Yabancı Diller Yüksek Okulundaki Temel İngilizce ve Modern Diller Bölümlerinde çalışan öğretim elemanlarıdır. Çalışmada önce anket cevapları incelenmiş, analiz değerlendirildikten sonra mülakat soruları hazırlanmıştır. Bu yöntem Creswell'in Açıklayıcı Sıralı Araştırma Yöntemi şeklinde bilinir. Araştırmacıların kendilerinin hazırladıkları anket çevrim içi ve afet dönemi literatürü gözden geçirilerek ve katılımcılarla benzer durumda olan 10 öğretim görevlisi ile konuşularak, onlara danışılarak hazırlanmışıtır. Anket soruları yaşanılan duygusal ve teknik zorluklar ve baş etme stratejileri üzerine yoğunlaşmıştır. Anket sonuçlarına göre gönüllü olan 24 öğretim görevlisi ile daha sonra çevrim içi mülakat yapılmış, elde edilen nitel verinin tematik analizi için kodlamada MAXQDA 2018 programı kullanılmıştır.

\section{BULGULAR, TARTIŞMA VE SONUÇLAR}

Araştırma aracı olarak uygulanan anket, genel olarak acil durum uygulaması öncesi öğretim görevlilerinin internet kullanımı ile alakalı farkındalıklarını test etmeyi amaçlamıştır. Tüm katılımcılar acil durum öncesi internet bağlantılarının olduğunu ve kurumda kullanılan sanal uygulama kapsamında ODTUclass öğrenme sistemine aşina olduklarını belirtmişlerdir. Sanal ortamda kullanılan en yaygın uygulamalar PowerPoint uygulaması, çevrim içi ders anlatım sistemleri ve ödev teslim etkinlikleri olarak belirlenmiştir. Bu kadar fazla sanal ortam uygulamalarına hâkim olmalarına rağmen tüm eğitim yüz yüze uygulandığında oldukça kalabalık bir öğretim görevlisi grubu ortamdan ve uygulama esaslarından endişe duyduklarını ve desteğe ihtiyaç duyduklarını hem anket hem de mülakat sonuçlarında belirtmişlerdir. Sonuçlar bu tür uygulamalara hakimiyetin "öğrenci-öğretmen" olmayı gerektirdiğini ve tüm öğretim görevlilerinin düzenli olarak dijital becerilerini geliştirmek için bireysel çalışmalar yapılması gerektiğini vurgulamıştır. Derslerin anlatılması dışında mülakatlarda öne çıkarılan bir nokta da ders değerlendirme sürecinin de çevrimiçi ortama taşınması ve alternatif değerlendirme süreçlerinin kullanılmaya başlanması olmuştur. Bölüm başkanlıkları acil dönemde dönemsel kararlar almaya çalışırken öğretim görevlileri aldıkları en büyük yardımın birlikte çalıştıkları hocalardan gelen destek olduklarını savunmuşlardır.

Öğretim görevlileri tarafindan gerek anket ve gerekse mülakat sonuçlarından çıkan bir takım negatif etkiler arasında öğrencilerin internet bağlantısı düzensizliği, bilgisayar, kulaklık ya da mikrofon yetersizlikleri gibi eksik ekipmanları nedeni ile derse olan motivasyon ve katılımlarının düşük olması da belirtilmiştir. Ancak öğrencilerin 
acil durum döneminden elde ettikleri en büyük başarı video kanallı öğretimler sayesinde dersleri tekrar izleme ve ders kaynaklarına erişimin sürekli olması olmuştur. Ayrıca kendi materyallerini takip etme ve zamanlarını etkin kullanma konusunda acil durum döneminin öğrencileri daha otonom öğreniciler hâline getirdiği de kabul edilmiştir. Katılımcılar, içinde bulunulan şartlar nedeni ile acil durum eğitim dönemini özellikle psikolojik açıdan panik duygusunu azaltmak, insanların sevdikleri ile birlikte olmak istediği bir zaman olarak ifade etmiş̧tir.

Avantajları olması ile birlikte acil durum döneminin öğretim görevlileri içi yarattı̆̆ en büyük sıkıntı iş-gerçek hayat arası denge kurulamaması olmuştur. Bazı öğrencilerin dijital yetkinliklerinin az olması ve bazı öğrencilerin de fazla talepkâr beklentileri nedeni ile öğretim görevlileri sürekli ulaşlabilir hâle gelmişlerdir. Acil durum eğitiminin öğretim görevlileri arasında fikir farkı yarattığı noktalar da olmuştur. Çevrim içi ortamda ders anlatmak mümkün iken bu durum yüz yüze eğitime kıyasla acil durum eğitimini daha fazla zaman kaybettirici hâle getirmiştir. Acil durum eğitimi ile ilgili en çarpıcı sonuçlardan biri bu dönemde elde edilen dijital becerilerin pandemi sonrası yüz yüze katılım döneminde de kullanılmaya devam edeceği gerçeği olmuştur.

Araştırmanın sonuçları, çevrim içi ortam ya da harmanlanmış eğitimlere geçmek isteyen kurumların öğretim görevlisi ve öğrencilerinin ihtiyaç analizlerini tespit etmelerini ve gerekli önlemleri almaları gerektiğini göstermiştir. Kurumların dijital ve ekipman olarak altyapılarını güçlendirmeleri ve hem öğretim görevlileri hem de öğrenciler için teknik destek sağlayacak elemanları hazır bulundurmaları gerekmektedir. Özellikle öğretim görevlilerinin dijital eğitim teknolojileri konusunda bilgilendirilmesi ve alternatif değerlendirme sistemleri konusunda farkındalık çalışmalarının artııılması gerekmektedir. Bu bakış açısı ile acil durum dönemi öğretim görevlileri için tam bir kişisel gelişim dönemi olmuş ve tüm öğretmenlerin zaruri olarak profesyonel hayatını etkileyen durum ilerisi için öğretim sistemlerinde doğal olarak yer almaya başlamıştır. Araştırmanın sonuçları eğitim fakültelerinde uygulanan eğitim programları için de yansımalar içermektedir. Bu tür programlarda yeni öğretmen adaylarına dijital eğitim teknolojilerinin tanıtılması ve zor şartlarda eğitim uygulanması gerektiğinde stresle başa çıkma gibi eğitimlerin verilmesi gerektiği sonucuna ulaşılmıştır.

\section{ARAŞTIRMANIN ETIK IZNI}

Bu çalışmada "Yükseköğretim Kurumları Bilimsel Araştırma ve Yayın Etiği Yönergesi” kapsamında uyulması gerektiği belirtilen tüm kurallara uyulmuştur. Yönergenin ikinci bölümü olan "Bilimsel Araştırma ve Yayın Etiğine Aykırı Eylemler" başlığı altında belirtilen eylemlerden hiçbiri gerçekleştirilmemiştir.

\section{Etik kurul izin bilgileri}

Etik değerlendirmeyi yapan kurul adı: Ortadoğu Teknik Üniversitesi İnsan Araştırmaları Etik Kurulu

Etik değerlendirme kararının tarihi: 4 Ağustos 2020

Etik değerlendirme belgesi sayı numarası: 28620816/235

\section{ARAŞTIRMACILARIN KATKI ORANI}

1. yazarın araştırmaya katkı oranı $\% 50$, 2. yazarın araştırmaya katkı oranı \%50'dir. İki yazar da araştırmanın tasarlanması, veri analizi, robotlaştırma, yöntemin belirlenmesi, danışmanlık, geçerlik ve güvenirlik çalışmalarına eşit şekilde katkıda bulunmuştur.

\section{DESTEK VE TEŞEKKÜR BEYANI}

Çalışmamızda kullandığımız anketin son haline ulaşmamızda bize katkısı olan tüm meslektaşlarımıza ve anketi cevaplayan, mülakatlarımıza vakit ve emek harcayan tüm katılımcılarımıza teşekkür ederiz.

\section{ÇATIŞMA BEYANI}

Bu çalışmada yazarların çalışma sonuçlarını etkileyecek maddi veya manevi çıkar çatışması yoktur. 